\title{
Space and Power in Byzantine Accounts of the Aerial Tollhouses
}

The idea that the souls of the deceased undertake a journey to heaven while adverse powers try to hinder their ascent was common to many religions in (Late) Antiquity. These adversaries were sometimes presented as military opponents and othertimes as tollkeepers (telonia). Byzantine Christianity elaborated upon the idea of the aerial tollkeepers: every soul, accompanied by benign angels, encounters tollhouses, which are guarded by demons. Each tollhouse is responsible for one kind of sin. The demons in each tollhouse demand satisfaction for the respective unconfessed sins, which the soul pays with good deeds done during lifetime. If a soul runs out of good deeds before it has passed through the last tollhouse, it is condemned.

The imagery of the tollkeepers was widespread among Byzantine Christians, coexisting with other, often contradicting notions. It was neither condemned nor officially recognised by the Byzantine Church. The stories of the aerial tollhouses reflect perceptions of power relations in the space between heaven and earth, between earthly life and places of eternal reward or damnation: whereas in other narratives the demons act as enemies or raiders in a disputed area, the demons sitting in the tollhouses function as executors of the divine law in a civil environment. Moreover, unlike apocalypses in which he acts as an absolute monarch, showing mercy at his will, God is not present in the accounts of the tollhouses. Yet in the imaginary landscape of these accounts there exists no space between heaven and earth which is not under God's distant, but undisputed reign.

\section{The Byzantine Church and the Afterlife: Preliminary Remarks}

When discussing notions of the afterlife in the Byzantine Church up to its demise in the fifteenth century, one has to bear in mind the pastoral (as opposed to systematic) character of the greater part of the extant theological literature written in Greek on things to come. The official teaching of the Byzantine Church consisted mostly of what was contained in the Creed as formulated by the fourth ecumenical council at Chalcedon in $451 \mathrm{CE}$ : “[Christ] shall come again, with glory, to judge the quick and the dead; whose kingdom shall have no end [...]. I expect the resurrection of the dead, and the life of the world to come." In this "life of the world to come", the

1 Staats, Das Glaubensbekenntnis von Nizäa-Konstantinopel.

ว Open Access. (C) 2020 Eirini Afentoulidou, published by De Gruyter. (ख) BY-NC-ND This work is licensed under the Creative Commons Attribution-NonCommercial-NoDerivatives 4.0 License.

https://doi.org/10.1515/9783110597745-025 
righteous would be rewarded with God's kingdom, whereas the sinners would be punished with eternal Hell. These very basic teachings were not enough to satisfy people's need to know about what was expecting them and their loved ones once they departed from this life. The details were filled in by the interaction with other late antique religions and belief systems of the Eastern Mediterranean. The main source for these notions was Judaism, and the channels of Jewish ideas' transmission were not only (what was largely seen as) canonical biblical literature (which, again, bore traces of various and at times diverging traditions), but also extracanonical apocalypses. ${ }^{2}$ Other sources were the Egyptian and Greek religions and especially regarding the notion of the aerial tollhouses - the religious movement of Gnosticism.

The hour of death, the judgment of the soul and the afterlife were common subjects in patristic and Byzantine literature. Authors made extensive use of images and motifs such as the ascent of the soul of the deceased, its encounter with hostile (demonic) powers, the weighing of the soul's deeds, its journey to the respective dwellings of the righteous or the sinners, or the universal judgment as a global stage, where all actions are laid bare while humans and angels are watching. ${ }^{3}$ However, such descriptions never reached the status of a dogma. Their function was mainly pastoral, aiming to motivate the audience towards a life in accordance with the teachings of the Church. Even if at times there were heated discussions among theologians about details of the afterlife, such as whether the promised Kingdom of Heaven is the Paradise in Eden, ${ }^{4}$ or whether the souls of the deceased can act in the time between death and resurrection, ${ }^{5}$ they were always conducted on an "unofficial" level. Their protagonists had no interest in initiating a process that could result in a binding church document. What such discussions show is that some Byzantine theologians were aware of contradictions regarding the afterlife in their tradition, including the Bible, and tried to rationalise them. Most of the time, however, even highly esteemed ecclesiastical writers used motifs and images of the afterlife without worrying about their theological implications.

The fluidity of the Byzantine Church's discourse on the afterlife may seem surprising for a Church that prided itself on preserving exact dogma. However, it was based on a widespread consensus among the theologically educated that there were many things, especially concerning death, that surpassed human understanding at least in the fallen state of humanity - and any attempt to explain them could only be tentative or figurative. In the fourth century, Gregory of Nyssa therefore called discussions on the human state after resurrection "conjectures":

2 Bauckham, The Fate of the Dead.

3 Afentoulidou, “"Exposed to the Eyes of all, upon the Public Theatre of the Universe'.”

4 Krausmüller, "What is Paradise and Who is in It?"

5 Constas, "To Sleep, Perchance to Dream;” also Eustratius of Constantinople, De Statu animarum, ed. Deun. 
Just as many questions might be started for debate amongst people sitting up at night as to the kind of thing that sunshine is, and then the simple appearing of it in all its beauty would render any verbal description superfluous, so every calculation that tries to arrive conjecturally at the future state will be reduced to nothingness by the object of our hopes, when it comes upon us. $^{6}$

The idea that higher knowledge could be attained only when one has laid aside the corporeal burden was common among Neoplatonic, Gnostic and Christian authors; ${ }^{7}$ however, what Gregory means here is the post-resurrection human state rather than an esoteric knowledge reached by few. In the seventh century, Anastasios of Sinai reached the following conclusion after attempting to explain why people die in different ways and at different stages in life: "[W]e have not said these things in an assertive and polemical way, but in a scientific spirit and as seems reasonable."8 Similarly, the monk Philippos in his popular work Dioptra, composed in 1095, avoids answering the question on the nature of the incorruptible body that humans will resume after the resurrection by arguing that it is impossible to know these things while still living in the corrupt world. ${ }^{9}$

The aerial tollhouses, which will be discussed in the present article, do not therefore represent "what the Byzantines believed about the afterlife". ${ }^{10}$ The motif was one of the many narratives used to conceptualise the soul's posthumous judgement. Although we have very few detailed accounts of the tollhouses, numerous allusions to it indicate that it was a very popular theme that did not need to be further explained to a Byzantine audience. The allusions to the aerial tollhouses occur mostly in texts of uncontested orthodoxy and always in an edifying context, aimed at motivating the audience to repent, do good, avoid evil, and seek God's mercy and the saints' or Mary's intercession: poems of contrition, hymns, exhortatory homilies, edifying tales. In more abstract theological treatises on the afterlife the tollhouses are not mentioned at all.

\section{The Ascent of the Soul and the Aerial Tollhouses}

The belief that the soul of the deceased rises through the air, encountering aerial powers which can hinder its ascent, was part of many religious systems of the

6 Gregory of Nyssa, De anima et resurrectione, 112.7-12, ed. Spira and Mühlenberg; translated by Moore and Wilson, St Gregory of Nyssa On the Soul and the Resurrection.

7 Cf. Lilla, Clement of Alexandria, 142-189.

8 Anastasios of Sinai, Questions and Answers, 28, trans. Munitiz, 124.

9 'H $\Delta \iota{ }^{\prime} \pi \tau \rho \alpha$, ed. Lavriotis, 141; republished in Prochorov, Bil'djug, Miklas and Fuchsbauer, "Dioptra" Filippa Monotropa. I am preparing a new edition, which will be published in the series CCSG. In my edition the verses are Diopra, IV, 411-420.

10 See Krausmüller, "How Widespread Was the Belief in Demonic Tollgates in Sixth- to Ninth-Century Byzantium?" 
ancient Near East. The prevailing hypothesis is that this notion was adopted by Eastern Christianity as a result of interaction with Gnosticism. ${ }^{11}$ The term tax collectors ( $\tau \varepsilon \lambda \tilde{\omega} v \alpha \mathrm{l})$ to denote these powers is first encountered in Greek in the Gospel of Thomas, a Gnostic text with Christian influences (dated probably to the first half of the third century CE), ${ }^{12}$ and appears in many Greek Christian texts thereafter. In Western Christianity demons as aerial tax collectors are unknown. As late antique and Byzantine texts employing the tollkeepers/tax collectors imagery have been discussed extensively in the last decades, I will not recount the textual evidence or the discussions on the origin of the tollhouses. ${ }^{13}$ Instead, I will discuss only a selection of texts, concentrating on the question of power relations in the space between death and Heaven. The journey through the tollhouses constitutes a judgment of the soul - a judgment executed in the space between the deathbed and the throne of God, but not by God. This is in striking contradiction to the Christian doctrine of an omnipotent, omnipresent God, and raises the question of power and authority in this liminal space. I will focus on two early Christian texts influenced by Gnosticism to a varying degree that use the motif of a password/passport, two monastic texts that employ the imagery of the battlefield and three Byzantine texts that depict a quasi-judicial process.

\subsection{Gatekeepers and Passwords}

A central teaching of Gnosticism was that the soul, in this life or after death, ascends through spheres towards a higher form of existence, the pleroma. The spheres were guarded by gatekeepers, who demanded a passport or password ( $\sigma$ ú $\mu \mathrm{o} \lambda$ ov,

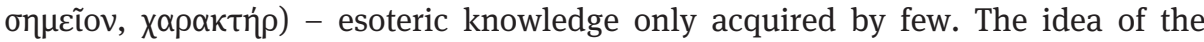
password is found in several late antique texts influenced by Gnosticism. In the possibly second-century text called the Ascensio Isaiae,${ }^{14}$ God the Father orders Christ to descend to earth through the seven gates of Heaven disguised as an angel, so that the angels who keep the gates do not recognise him. From the third gate downwards the angels demand a password, which Christ gives, so as not to be recognised. The procedure is introduced with the following or a similar formula: And those who kept the gate of the (third) Heaven demanded the password (māxlaft),

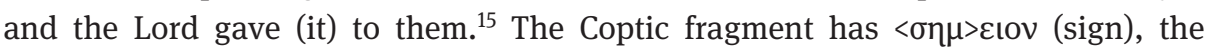

11 Bousset, "Die Himmelsreise der Seele;” Recheis, Engel, Tod und Seelenreise.

12 Bartelink, "TE $\Lambda \Omega N A I . "$

13 Marinis, Death and the Afterlife in Byzantium; Afentoulidou, "Gesellschaftliche Vorstellungen in den byzantinischen Berichten;" Bartelink, "TE $\Lambda \Omega N A I . "$

14 Ascensio Isaiae, 10.7-31, ed. Norelli, vol. 2.

15 Ascensio Isaiae, ed. Norelli, translates "lasciapassare". See the comments in Ascensio Isaiae, ed. Norelli, vol. 2, 529-533. 
Slavonic translation znamenije, the Latin character. ${ }^{16}$ In this passage the gatekeepers are angels and they are in the service of God, ensuring that only the worthy enter the gates of Heaven. However, they seem to have acquired a certain degree of autonomous authority: it appears that it is not possible for God to order his angels to let somebody through without asking questions.

The Gnostic terminology of gatekeepers and passport/password is used in one of the earliest patristic mentions of tollkeepers, the Stromateis (literally "patchwork") written by Clement of Alexandria around the year 200 CE:

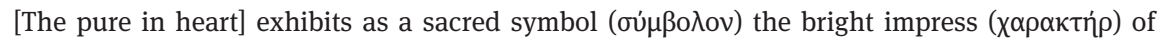

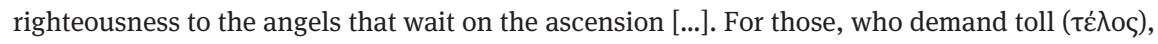
detain those who bring in any worldly things, who are burdened with their own passions. But him that is free of all things which are subject to duty, and is full of knowledge ( $\pi \lambda \lambda^{\prime} \rho \eta \gamma v \omega \dot{-}-$ $\sigma \varepsilon \omega \varsigma)$, and of the righteousness of works, they pass on with their good wishes, blessing the man with his work. ${ }^{17}$

As in the Ascensio Isaiae, the gatekeepers are angels. God is completely absent, but the fact that the angels are benign to the righteous implies that they are in God's service. The Gnostic discourse permeates the text: the virtue that humans practice is compared to a permit, and the virtuous is "full of knowledge". However, the biblical discourse of righteousness of works puts the privileged, esoteric character of the "passport” into perspective.

\subsection{Demonic Opponents}

In several late antique and early Byzantine texts originating mainly from monastic circles in Egypt and the Near East, demons try to obstruct a human's way to God's throne using physical power. This journey to God's throne may refer to the everyday spiritual struggle of the ascetic whilst alive or to the posthumous ascent of the soul. Texts using a martial discourse often quote or allude to a passage from the Letter to the Ephesians attributed to St Paul:

Grow strong in the Lord, with the strength of his power. Put on the full armour of God so as to be able to resist the devil's tactics. For it is not against human enemies that we have to struggle, but against the principalities and the ruling forces who are masters of the darkness in this world, the spirits of evil in the Heavens. That is why you must take up all God's armour, or you

16 Ascensio Isaiae, ed. Norelli, vol. 1, 182-183.

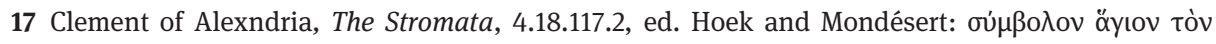

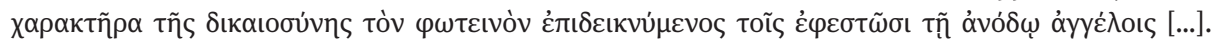

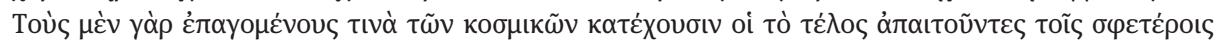

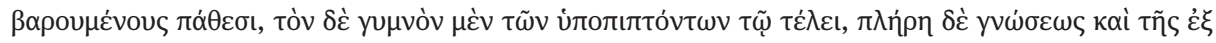

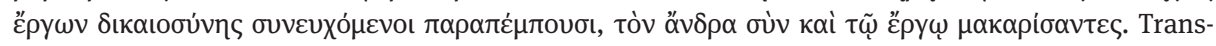
lated by Wilson, Clement of Alexandria: The Stromata. 
will not be able to put up any resistance on the evil day, or stand your ground even though you exert yourselves to the full. So stand your ground, with truth a belt round your waist, and uprightness a breastplate, wearing for shoes on your feet the eagerness to spread the gospel of peace and always carrying the shield of faith so that you can use it to quench the burning arrows of the Evil One. And then you must take salvation as your helmet and the sword of the Spirit, that is, the word of God (Eph 6:10-17).

In this passage the whole world, including the air, is under the rule of the masters of the darkness. God's assistance is visualised in parts of armour, that is, objects that are very close to one's body, for the whole terrain is under the power of evil.

In many Christian texts "the evil day" of the Letter to the Ephesians is interpreted as referring to the hour of death. This is the case in homily 22 by Symeon Stylites the Younger from sixth-century Syria. ${ }^{18}$ This homily, written in Greek, treats exclusively the hour of death, exhorting listeners to follow a way of life according to God's commandments. The author uses rapidly changing powerful images rather than a linear narration. According to the homilist, the soul of the deceased, armed with its virtues, undertakes a journey through a dangerous land to the throne of God. On its way it has to face demons, who under their leader, the devil, try to defeat it and drag it to Hell. The homily's beginning both cites and echoes the Letter to the Ephesians. Its vocabulary is used throughout the homily, such as when the demons are called "ruling forces" ${ }^{19}$ Martial terms abound: the devil raids, ${ }^{20}$ the angels embolden the soul, ${ }^{21}$ the soul fights against ${ }^{22}$ and wins over ${ }^{23}$ the demons etc. An element absent from the Letter to the Ephesians but central in many Christian narrations is the company of angels. In Symeon Stylites' narration angels encourage the soul and prepare it for the struggle, but, in contrast to later accounts, they are not otherwise involved. God is sitting at the end of the route, awaiting those who make it through the dangerous territory, but is himself completely absent from the battlefield. Thus between the soul's deathbed and the throne of God there exists a space with its own rules, in which God and his angels have no power. Terms borrowed from civil administration also imply that this space is governed by the demons: besides being named a chief tollkeeper, ${ }^{24}$ the devil himself is described as a judge in the air ${ }^{25}$ - an unusual image, since it is usually Christ who is depicted as a judge. However, although the use of the word "judge" implies some kind of

18 Symeon Stylites the Younger, Homily, 22, ed. Cozza-Luzi, 111-118.

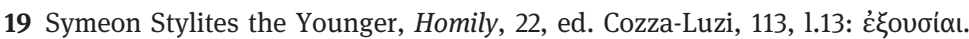

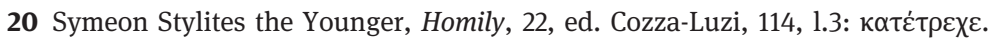

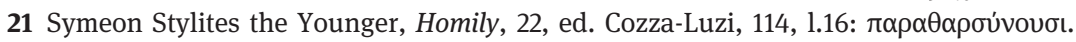

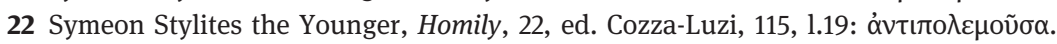

23 Symeon Stylites the Younger, Homily, 22, ed. Cozza-Luzi, 116, 1.1: vıкпбóбns.

24 Symeon Stylites the Younger, Homily, 22, ed. Cozza-Luzi, 112, 1.2-3: $\dot{\alpha} \rho x ı \tau \varepsilon \lambda \omega ́ v o v$.

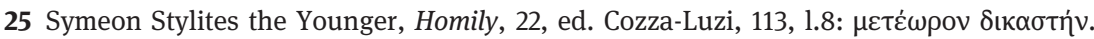


power, the devil does not decide himself, but awaits the outcome. ${ }^{26}$ Moreover, the demons drag the souls they manage to overpower to Hell: the battlefield is not their proper territory either.

Much shorter is the account in Homily 43 of Pseudo-Makarios, presumably from the late fourth or early fifth century CE:

Like tax-collectors sitting in the narrow way, and laying hold upon the passers-by, and extorting from them, so do the devils spy upon souls, and lay hold of them; and when they pass out of the body, if they are not perfectly cleansed, they do not suffer them to mount up to the mansions of Heaven. ${ }^{27}$

Although there is no battle here, the detail that the tollkeepers sit at narrow streets marks a shift from the gatekeeper-imagery: they are not God's servants, but are implicitly likened to lurking raiders. Unlike in Symeon Stylites the Younger's narration, they are not powerful enough for an open battle. Still, God's rule in this liminal space is not secure enough to guarantee a soul's safe passage either. Arguably, it is God's law that the tollkeepers execute; any author who employed the imagery of the tollkeepers would hardly deny that the demons only do whatever God allows. But even if the tollkeepers are a conceptualisation of God's judgment, the details of the imagery reveal notions of power and authority.

At the beginning of a further text, a vision attributed to the fourth-century hermit Makarios of Egypt but probably of much later date, the angels escort the soul towards God's throne. The encounter with the demons is described in the following words: "Some black and dark ones in the air were very busy trying to snatch the souls of the humans and drag them down. But the angels resisted strongly and forcefully by flogging them."28

The human soul remains passive throughout the journey. This passivity stands in contrast to the passage from Paul's Letter to the Ephesians and the previously mentioned homily by Symeon the Stylite, but it is typical of most later accounts of the tollhouses. The constellation at the battle also reveals different power relations: in Symeon's homily the angels stay away from the battlefield, on which the demons seem to have the upper hand. In the vision attributed to Makarios, the angels are ordered by God to escort the soul; this is a space in which God's orders are carried

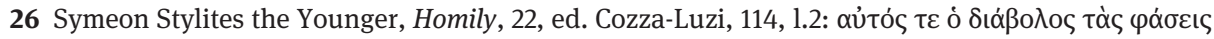

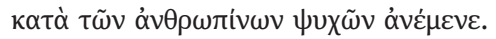

27 Pseudo-Makarios, Die 50 Geistlichen Homilien des Makarios, ed. Dörries, Klostermann and

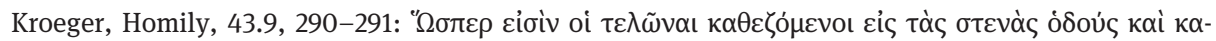

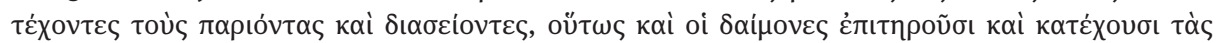

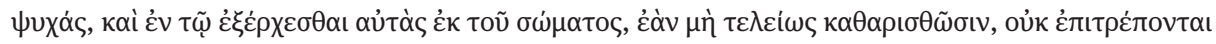

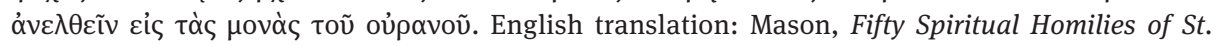
Macarius the Egyptian, 274.

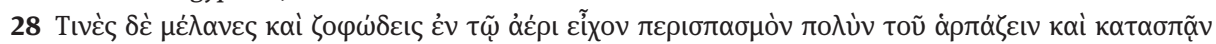

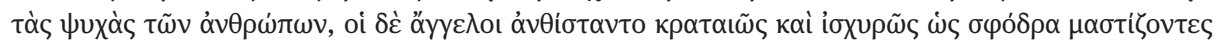
aủtoùc. Visiones de sanctis angelis, PG 34, 224 C. 
out by his messengers. However, God himself does not appear, and the demons are still active in this space. And yet, they do not act as somebody who has authority, but as raiders who try to snatch the soul. In the passage quoted, which is from the beginning of the vision, the struggle between angels and demons is entirely physical. In the second part of the same vision, however, the scenario changes from military to bureaucratic, and the demons take up the function of clerks sitting at their tollhouses. It is this function of the demons as tollkeepers that I will discuss in the following section.

\subsection{A Judicial Process}

The very term tollkeepers/tax collectors belongs to a fiscal/legal discourse - fiscal matters and justice were not strictly separated in Byzantium. ${ }^{29}$ In the course of the centuries the juridical elements become more pronounced, whereas the military discourse diminishes.

A detailed and systematic account of the tollhouses' procedure is first given in the tenth-century Vision of Theodora in the Life of St. Basil the Younger, which will be discussed below. ${ }^{30}$ However, the details given in numerous earlier mentions and short texts from the end of Late Antiquity onwards reveal a high degree of consistency regarding the procedure of the judgment: every soul, escorted by two benign angels, has to pass various tollhouses guarded by demons. There is a tollhouse for each different kind of sin. The demons in each tollhouse demand satisfaction for the respective unconfessed sins, which the soul pays with good deeds done during its lifetime. If a soul runs out of good deeds before it has passed the last tollhouse, the demons take possession of it. If it can pay off every sin, it reaches its goal, which is the throne of God.

The first account to be examined here is again the vision of Makarios. The first part of the vision, as discussed above, describes physical fights between angels and demons, but the second part consists of scenes of quasi-legal procedures. In one scene, the demons accuse a man of fornication, sodomy and verbal abuse. The angels claim that he had repented in time, which the demons doubt. Both parts agree to summon the guardian angel of the aforesaid man as a witness. The guardian angel testifies that his protégé had confessed his sins before he died. His testimony is accepted and the man is saved. ${ }^{31}$

The next account is the story of the Carthaginian, who is a civil servant according to one version, a soldier according to another. The story, set in the seventh century, is transmitted both independently and, with minor variations, as part of the

29 Magdalino, "Justice and Finance in the Byzantine State."

30 Vita Basilii Iunioris (BHG 264). Editions: The Life of Saint Basil the Younger, ed. Sullivan, Talbot and McGrath, and Žitie sv. Vasilija Novago, ed. Vilinskij (version of cod. Athon. Iberon 478).

31 Visiones de sanctis angelis, o.c. 224 D-225 C. 
ninth-century Chronicle of Georgios Monachos. ${ }^{32}$ The fact that it appears in various contexts and versions is typical of how such stories circulated; it is a reminder that the dissemination of stories and images regarding the telonia was not restricted to written sources. In this story, an unnamed Carthaginian dies in sin. After struggling his way through the first telonia, he runs out of good deeds. As he reaches the tollhouse of fornication, the demons bring forth all the sins from his youth against him. The angels claim that he had confessed these sins. The demons accept this defence, but reveal one last unconfessed sin. The angels immediately admit that the demons have won. The man is about to be taken away by the demons, but in a miraculous way he is released back to life, where he reports his posthumous fate, repents and dies a few days later.

The last text comes from the vision of Theodora, which is part of the tenth-century Life of Saint Basil the Younger. Theodora had been Saint Basil's faithful slave in her final years. When she dies, the saint's disciple, Gregory, worries about her posthumous fate. Theodora appears to him in a vision and reveals what she went through from the hour of her death until she entered the Heavenly Kingdom. While Theodora still lay on her deathbed, terrified by the surrounding demons, two angels came to her aid and collected all her good deeds. At that point Saint Basil appeared and gave her a bag of gold from his own good deeds as a reward for her good services. Endowed with the treasure of good deeds, both her own and Basil's, Theodora and the angels set off on their journey through twenty-one tollhouses, all guarded by demons. At some tollhouses, such as the one for maliciousness, avarice or heartlessness, the tollkeepers found nothing against her, and Theodora and the angels passed easily. At other tollhouses, such as the ones for excessive wine drinking and gluttony, the angels, acting as Theodora's attorneys, readily paid from her good deeds. At some other tollhouses the outcome was not obvious and a quasi-judicial struggle between the angels and the demonic tollkeepers took place, until both parties reached an agreement. For example, the demons sitting at the tollhouse of adultery accused Theodora of having cheated on her husband. The angels did not contest this fact, but tried to argue for a milder penalty for their client by claiming that, as a slave, Theodora was not married to her man; therefore, cheating on him should be categorised not as the sin of adultery, but of fornication. The demons retorted with an equally quasi-legal argument: the master of the slave is like a second God; therefore, the man that was given to Theodora by her previous mistress was equal to a husband; therefore, cheating on him was adultery. Theodora then tells Gregory

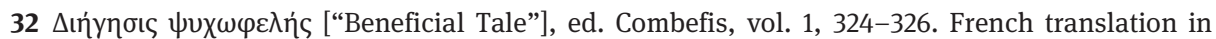
Léontios de Néapolis, ed. Festugière and Rydén, 613-616 and Georgii Monachi Chronicon, 575-578, ed. Boor, 678.16-683.2. In the first version the story is set at the time of the patrician Nicetas (fl. ca. 609-617), in the Chronicle of Georgios Monachos at the time of emperor Constantine III (641). Carthage was destroyed in 698. Festugière identified the Nicetas of the first version with John the Almgiver's adoptive brother (o.c., 613). See Martindale, Prosopography of the Later Roman Empire III, 940-943, s.v. Nicetas 7. 
that this argument went on for some time and that the angels won, without giving further details. ${ }^{33}$ She was not spared the accusation of fornication though, which she eventually paid off by good deeds.

Theodora's motives were also taken into consideration in the mini-trials at the tollhouses. Thus the tollkeepers responsible for wrath accused Theodora of having castigated her children, whereas she claimed that this had not been an act of wrath, but that she had corrected her children to teach them, and out of love. ${ }^{34}$

According to accounts of the tollhouses such as the ones described above, the space between earth and Heaven is administered by a perfectly functioning justice system. The formerly raiding demons are tamed and become part of this system not as judges, but as plaintiffs, who demand what belongs to them. They are still hostile to the humans, but they claim their rights by appealing to the law. The angels act as attorneys. Neither the angels, nor the demons have the power to influence the outcome of the trial, which is solely the result of the sum of good and bad deeds. God is absent from this space. It is not God's power to which this space is subjected, but an impersonal justice system. The forensic nature of the struggle over a soul reveals a high degree of consensus between angels and demons. Both parts respect the "universal" (i.e. the Byzantine) law and act within its frame. Evidence and valid arguments are accepted. Both parts are highly motivated and fight for their cause to the end, regardless of whether the person they accuse or defend is a sinner, but nobody contests the outcome of the process.

Everything is small-scale and almost private: there is no global theatre with a universal judge and myriads of angels and saints as spectators. ${ }^{35}$ There are only two angels, some demons at each tollhouse, and a single human soul. The human soul is not expected to perform any heroic feats in its encounter with the demons. It can only be escorted through this huge bureaucratic system and watch as the angels and the demons argue about every single deed of its earthly life. Compared to the battle scenes in accounts such as in the homily attributed to Symeon, posthumous human agency in accounts of the aerial tollhouses is very much restricted. Indeed,

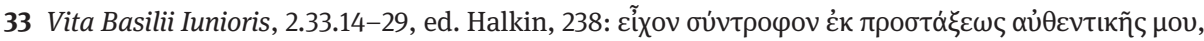

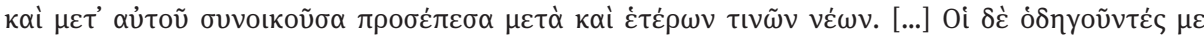

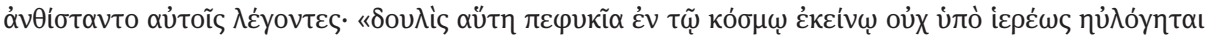

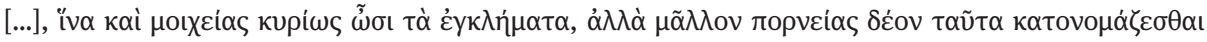

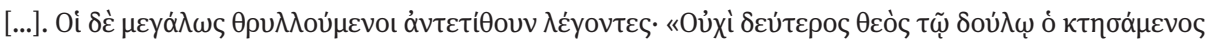

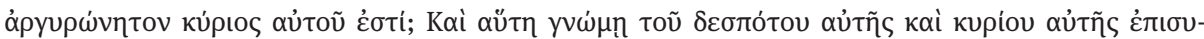

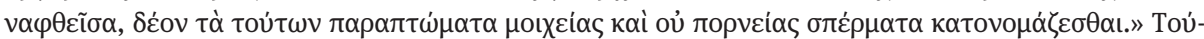

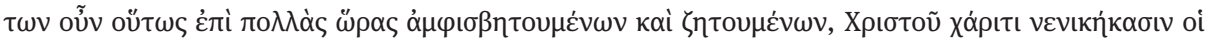

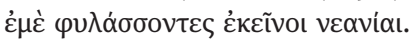

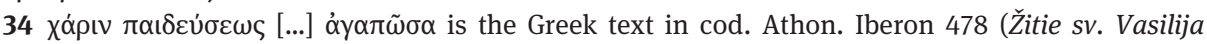
Novago, 17.38-39, ed. Vilinskij). In the Moscow version (Life of Saint Basil the Younger, 2.16.14, ed. Sullivan, Talbot and McGrath, 214) $\alpha$ ' $\alpha \pi \tilde{\omega} \sigma \alpha$ is missing.

35 Afentoulidou, “'Exposed to the Eyes of All, upon the Public Theatre of the Universe'.” 
the deceased person never answers the demons him- or herself. It is the accusations of the demons and the answers of the angels that steer the events.

The soul cannot expect any help from God or from human friends, not even from the intercession of the Mother of God, which is so important in other accounts of the afterlife. ${ }^{36}$ Nobody is exempted from the tollhouses, and no one has so much influence as to intervene on behalf of somebody else. Even the gold Theodora accepts posthumously from Basil is a sign that both share the same status, albeit with different achievements: Basil cannot exempt Theodora from the tollhouses, he will pass through them himself someday, and the deeds of both the holy man and the slave woman are converted into the same currency. This comes in sharp contrast to Gnostic notions of the enlightened few who possess privileged knowledge in form of a passport or password. Theodora and the Carthaginian man are explicitly persons of no special religious status. The absolute ruler is absent, and everybody else is subject to the same bureaucracy.

The peace and security guaranteed by a strong omnipresent administration, the remoteness of a ruler, the private character of the process, the passivity of the individual in its encounter with the bureaucracy, and its self-reliance as opposed to trust in social networks, are the main features of the imagined space between Heaven and earth. And perhaps this is how some of the Christians of the Eastern Roman Empire perceived power relations in their earthly world.

\section{Bibliography}

\section{Abbrevations}

BHG Bibliotheca Hagiographica Graeca. Edited by François Halkin. Brussels: Société des Bollandistes, 1957-1984.

CCSG Corpus Christianorum Series Graeca. Edited by Marcel Richard. Turnhout: Brepols, 1976-.

CCT Corpus Christianorum in Translation. Turnhout: Brepols, 2009-.

CPG Clavis Patrum Graecorum. Vols. 1-5. Edited by Maurits Geerard. Turnhout: Brepols, 19742003.

PG Patrologiae Cursus Completus, Series Graeca. Edited by Jacques-Paul Migne. Paris: Imprimerie Catholique, 1857-1866.

\section{Primary Sources}

Anastasios of Sinai. Questions and Answers. Translated by Joseph S. J. Munitiz. CCT 7. Turnhout: Brepols, 2011.

36 Peltomaa, Külzer and Allen, Presbeia Theotokou; Baun, Tales from another Byzantium. 
Ascensio Isaiae. Vol. 1: Textus, Vol. 2: Commentarius et Indices. Edited by Enrico Norelli, Alda Giambelluca Kossava, Claudio Leonardi, Lorenzo Perrone, and Paolo Bettiolo. Turnhout: Brepols, 1995.

The Life of Saint Basil the Younger: Critical Edition and Annotated Translation of the Moscow Version. Edited by Denis F. Sullivan, Alice-Mary Talbot and Stamatina McGrath. Vol. 45, Dumbarton Oaks Studies. Washington, DC: Dumbarton Oaks Research Library and Collection, 2014.

Clement of Alexandria. The Stromata, or Miscellanies. Ante-Nicene Christian Library. Vol. 2. Translated by William Wilson. Edinburgh: T. \& T. Clark, 1885; and also: Clément d'Alexandrie. Les stromates IV. Introduction, téxte critique et notes. Edited by Annewies van den Hoek and Claude Mondésert and translated by Claude Mondésert, S. J. Paris: Éditions du Cerf, 2001.

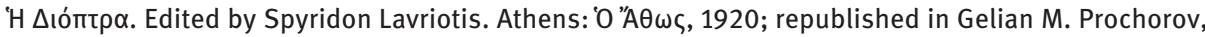
A. B. Bil'djug, Heinz Miklas and Jürgen Fuchsbauer eds. "Dioptra" Filippa Monotropa. Antropologičeskaja enciklopedija pravoslavnogo srednevekov’ja, Moscow: Nauka, 2008.

Dioptra. Edited by Eirini Afentoulidou. CCSG. Turnhout: Brepols, forthcoming.

Eustratius of Constantinople (Eustratii Presbyteri Constantinopolitani). De Statu animarum post mortem. Edited by Peter van Deun. CPG 7522. Turnhout: Brepols, 2006.

Georgius monachus. Chronicon, vol. 1-2, corr. Peter Wirth. Edited by Carl de Boor. Leipzig, 1904; Stuttgart: Teubner 1978.

Gregory of Nyssa (Gregorii Nysseni). De anima et Resurrectione. Opera Dogmatica Minora. Edited by Andreas Spira, Wolfram Brinker and Ekkehard Mühlenberg. Leiden-Boston: Brill, 2014.

Gregory of Nyssa (Gregorii Nysseni). On the Soul and the Resurrection. Translated by William Moore and Henry Austin Wilson. In Nicene and Post-Nicene Fathers: A Select Library of the Christian Church. Second Series, edited by Philip Schaff and Henry Wace. New York: The Christian literature company - Oxford: Parker Co., 1893.

$\Delta ı n \eta \eta \sigma \varsigma ~ \psi u x \omega \varphi \varepsilon \lambda \eta \dot{\varsigma}$ (“Beneficial Tale”). In Bibliothecae patrum graecorum auctarium novissimum I, edited by François Combefis, 324-326. Paris, 1672.

Macarius Magnus, Homiliae. PG 34, 449-822. Paris: Imprimerie Catholique, 1857-1866.

Fifty Spiritual Homilies of St. Macarius the Egyptian. Translated by James A. Mason. New York: The Macmillan Company, 1921.

Pseudo-Makarios. Die 50 Geistlichen Homilien des Makarios. Edited by Hermann Dörries, Erich Klostermann and Matthias Kroeger. CPG 2411. Patristische Texte und Studien 4. Berlin: De Gruyter, 1964.

Symeon Stylites the Younger. Homilies. In Nova Patrum Bibliotheca VIII.III. Edited by Giuseppe Cozza-Luzi, 4-156. CPG 7367. Roma: Ex Bibliotheca Vaticana, 1871.

Vie de Syméon le Fou et Vie de Jean de Chypre / Léontios de Néapolis; édition commentée par A.J. Festugière en collaboration avec Lennart Rydén. Edited and translated by André-Jean Festugière and Lennart Rydén. Paris: Geuthner 1974.

Žitie sv. Vasilija Novago v russkoj literature. Vol. I.II. Edited by Sergei G. Vilinskij. Odessa, 19111913 (version of cod. Athon. Iberon 478).

\section{Secondary Literature}

Afentoulidou, Eirini. "Gesellschaftliche Vorstellungen in den byzantinischen Berichten von posthumen Zollstationen.” Zeitschrift für Religions- und Geistesgeschichte 67, no.1 (2015): 1742.

Afentoulidou, Eirini. “'Exposed to the Eyes of all, upon the Public Theatre of the Universe'. The Last Judgement in Byzantium." In The Bible in Byzantium: Appropriation, Adaptation, Interpretation, 
edited by Claudia Rapp and Andreas Külzer, 107-121. Göttingen: Journal of Ancient Judaism, Supplements, 2019.

Bartelink, Gerhardus J. M. “TE $\Omega$ NAI (Zöllner) als Dämonenbezeichnung.” Sacris Erudiri 27 (1984): 5-18.

Bauckham, Richard. The Fate of the Dead. Studies on the Jewish and Christian Apocalypses. Leiden, Boston, Köln: Brill, 1998.

Baun, Jane. Tales from another Byzantium. Celestial Journey and Local Community in the Medieval Greek Apocrypha. Cambridge: Cambridge University Press, 2007.

Bousset, Wilhelm D. “Die Himmelsreise der Seele.” Archiv für Religionswissenschaft 4 (1901): 136169, 229-273.

Constas, Nicholas. “'To Sleep, Perchance to Dream’: The Middle State of Souls in Patristic and Byzantine Literature.” Dumbarton Oaks Papers 55 (2001): 91-124

Krausmüller, Dirk. "What is Paradise and Who is in It? The Discussion about the Abode of the Souls of the Righteous in Sixth- to Eleventh-Century Byzantium.” Byzantinoslavica 75 (2018).

Krausmüller, Dirk. “How Widespread Was the Belief in Demonic Tollgates in Sixth- to Ninth-Century Byzantium?” Byzantinische Zeitschrift 112 (2019): 83-102.

Lilla, Salvatore R. C. Clement of Alexandria: A Study in Christian Platonism and Gnosticism. Oxford: Oxford University Press, 1971.

Magdalino, Paul. "Justice and Finance in the Byzantine State, Ninth to Twelfth Centuries." in Law and Society in Byzantium, Ninth-Twelfth Centuries, edited by Angeliki Laiou and Dieter Simon, 93-115. Washington, D.C.: Dumbarton Oaks Research Library and Collection, 1994.

Marinis, Vasileios. Death and the Afterlife in Byzantium. The Fate of the Soul in Theology, Liturgy and Art. Cambridge: Cambridge University Press, 2017.

Martindale, Robert John, ed. Prosopography of the Later Roman Empire III. Cambridge: Cambridge University Press, 1992.

Peltomaa, Mari Leena, Andreas Külzer and Pauline Allen, eds. Presbeia Theotokou. The Intercessory Role of Mary across Times and Places in Byzantium (4th-9th Century). Vienna: Verlag der Österreichischen Akademie der Wissenschaften, 2015.

Recheis, Athanas. Engel, Tod und Seelenreise. Das Wirken der Geister beim Heimgang des Menschen in der Lehre der alexandrinischen und kappadokischen Väter. Rome: Ed. di Storia e letteratura, 1958.

Staats, Reinhard. Das Glaubensbekenntnis von Nizäa-Konstantinopel. Historische und theologische Grundlagen. Darmstadt: Wissenschaftliche Buchgesellschaft, 1996. 